BEAUTY OR STATISTICS

Practice and Science in Dutch Livestock Breeding, 1900-2000 



\section{Beauty or Statistics}

Practice and Science in Dutch Livestock Breeding, 1900-2000

\section{BERT THEUNISSEN}

With the collaboration of Steven van der Laan, Jesper Oldenburger, and Liesbeth van der Waaij 
(C) University of Toronto Press 2020

Toronto Buffalo London

utorontopress.com

Printed in the U.S.A.

ISBN 978-1-4875-0700-8 (cloth) ＩSBN 978-1-4875-3539-1 (EPUB)

ISBN 978-1-4875-3538-4 (PDF)

\section{Library and Archives Canada Cataloguing in Publication}

Title: Beauty or statistics : practice and science in Dutch livestock breeding, 1900-2000 / Bert Theunissen ; with the collaboration of Steven van der Laan, Jesper Oldenburger, and Liesbeth van der Waaij.

Names: Theunissen, Bert, 1955- author.

Description: Includes bibliographical references and index.

Identifiers: Canadiana (print) 20190204605 | Canadiana (ebook) 20190204664 |

ISBN 9781487507008 (hardcover) | ISBN 9781487535384 (PDF) |

ISBN 9781487535391 (EPUB)

Subjects: LCSH: Livestock - Breeding - Netherlands - History -

$20^{\text {th }}$ century. $\mid$ LCSH: Livestock - Netherlands - History $-20^{\text {th }}$ century.

Classification: LCC SF105.25.N4 T44 2019 | DDC 636.08/2 - dc23

University of Toronto Press acknowledges the financial assistance to its publishing program of the Canada Council for the Arts and the Ontario Arts Council, an agency of the Government of Ontario.

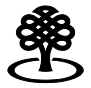

Canada Council for the Arts

\section{Conseil des Arts} du Canada

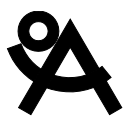

ONTARIO ARTS COUNCIL CONSEIL DES ARTS DE L'ONTARIO

an Ontarlo government agency un organisme du gouvernement de l'Ontario
Funded by the Financé par le Government gouvernement of Canada du Canada 